九州大学学術情報リポジトリ

Kyushu University Institutional Repository

The Currency of "Tradition" in Recent Exhibitions of Contemporary Japanese Art

Foxwell, Chelsea

University of Chicago: Associate Professor, Dpartment of Art History

https://doi.org/10.5109/2231581

出版情報: Journal of Asian Humanities at Kyushu University. 4, pp.57-76, 2019-03. Kyushu University, School of Letters, Graduate School of Humanities, Faculty of Humanities バージョン:

権利関係 : 


\title{
The Currency of "Tradition" in Recent Exhibitions of Contemporary Japanese Art
}

\author{
EXHIBITION REVIEW BY CHELSEA FOXWELL
}

$\mathbf{T}$ $\mathrm{HE}$ tone of several recent exhibitions in New York, Honolulu, Chicago, Boston, and Tokyo shows that the theme of tradition, however construed, remains prominent in contemporary Japanese art. This is perhaps unsurprising: as Keith Moxey emphasized in his book Visual Time (2013), "Modernity and its artistic partner, modernism, have always been tied to the star of temporal progress. The time of modernity is teleological, and its home lies in the West." From the beginning of the twentieth century to the present day, artists who were born, trained, or who work in Asia, Africa, and Central and South America, and whose artistic heritage may be unfamiliar to many viewers, seem to field more than their fair share of questions about the role of "tradition" in their art.

Tradition is sited far from modernism's historic centers because "it was only possible for Western powers to aspire to control the rest of the globe's culture if [non-Western locales] were characterized not only as spatially exotic but also as temporally backward."2 With Euro-America serving as modernity's home base, the

This article originated in a presentation delivered at the University of Hawai'i at Mānoa. I am grateful to the editors and to the anonymous reviewers for their comments and suggestions.

1 Moxey, Visual Time, p. 11

2 Ibid. local culture of a place like Japan was instantly consolidated as "tradition," a word that had no precise Japanese counterpart in the noun form prior to the 1880 os. $^{3}$ Japanese interlocutors in the seventeenth through nineteenth centuries were more likely to speak of cultural practices as foundations or transmissions (honrai no giho 本来の技法, denju 伝授, etc.), concepts that emphasize the past while still accommodating development and renewal. It was only in the face of modernism's emphasis on rupture, disinheritance, and critical resistance to the past that the concept of transmission began to seem inadequate or unmodern. ${ }^{4}$

Modernism expressed antipathy toward art's transmissive function and consequently expressed tradition as something static and tangible. In Japan, accordingly, it was only with the growing reliance on concepts of the modern and stylishly occidental that dentō 伝統 (tradition) emerged as an important term in artistic discourse. ${ }^{5}$ Modernity and tradition were conceptually opposed within a mode of thinking that associated Euro-American culture with progress and power. Since then, one important function of tradition-based art has

3 Foxwell, "The Painting of Sadness?"

4 Latour, We Have Never Been Modern, p. 10; Horowitz, Sustaining Loss.

5 Foxwell, "The Painting of Sadness?," pp. 39-40. 
been the positing of other roles for inherited materials and techniques apart from that oppressive binary. Examples of tradition-based Japanese art in the spotlight include The Metropolitan Museum's showcasing of the contemporary porcelains of Fukami Sueharu 深見陶治 (b. 1947) and the bamboo installations of Tanabe Chikuunsai IV 田辺竹雲斎 (b. 1973). ${ }^{6}$

In 2007, Gennifer Weisenfeld considered the role of tradition in contemporary Japanese art in her article, "Reinscribing Tradition in a Transnational Art World (2007)." Focusing on themes from the Edo period (1615-1868) in the work of Murakami Takashi 村上 隆 (b. 1962) and Araki Nobuyoshi 荒木経惟 (b. 1948), Weisenfeld's article warned that in the hands of successful artists and art promoters, Japanese "tradition" is far from neutral or genteel. At times a seemingly shallow and "lucrative commodification of difference," tradition can also be "slyly inverted to support nationalist ideologies of cultural essentialism." In short, Weisenfeld found the concept of tradition being put to multiple, sometimes conflicting, uses in contemporary Japanese art. ${ }^{7}$ In the intervening decade or so since the publication of her article, tradition has maintained a continued if not increased prominence in contemporary exhibitions of Japanese art. This suggests that far from subsiding in the face of caveats, tradition-based art has developed and expanded in ways that warrant renewed attention.

Why has the overt allusion to past Japanese art become so popular among younger and mid-career Japanese artists, especially those looking to establish themselves abroad? The present review, rather than offering new research, takes stock of recent developments in the international field of tradition-based contemporary art. I hope to offer a new hypothesis by proposing two opposing poles, namely, criticality and the suspension of criticality, along which contemporary Japanese art's visual discourse on "tradition" might be ranged. Artists to be considered include Kimura Ryōko 木村了子 (b. 1971), Tenmyouya Hisashi 天明屋尚 (b. 1966), Teraoka Masami 寺岡政美 (b. 1936), Murakami Takashi, Mori Mariko 森万里子 (b. 1967), teamLab 千

6 Tanabe Chikuunsai IV, Japanese Bamboo Art: The Abbey Collection, 13 June 2017-4 February 2018; Fukami Sueharu, A Sensitivity to the Seasons: Spring and Summer, 17 December 2005-4 June 2006, and Birds in the Art of Japan, 2 February 2013-28 July 2013. The Metropolitan Museum of Art, New York.

7 Weisenfeld, "Reinscribing Tradition," p. 372.
ームラボ (estd. 2001), and Kambe Tomoyuki 神戸智 行 (b. 1975). Rather than simply discounting certain tradition-based works for a seeming lack of criticality, a more audience-centered approach can examine the appeal or currency of such works among viewers worldwide, including younger viewers and art world outsiders.

In the exhibition Imayō: Japan's New Traditionists (今様: 昔と今をつなぐ Imayō: Mukashi to ima o tsu$n a g u$; University of Hawai' $i$ and Honolulu Museum of Art, 2016; Tokyo, Shōtō Museum, 2017), John Szostak used the term "historicism" to describe the overt allusion to and embrace of past Japanese art. He points out that historicism has become popular among younger and mid-career Japanese artists of international repute, and his approach brings to mind the works presented in the exhibition Garden of Unearthly Delights: Works by Ikeda, Tenmyouya, and teamLab (curated by Miwako Tezuka, Japan Society New York, 2014). The pieces in these two exhibitions look visibly Japanese, and overtly reference past Japanese art. Visible references to past Japanese art are also apparent in consecutive American exhibitions featuring recent work by Murakami Takashi at the Museum of Contemporary Art, Chicago, and the Museum of Fine Arts, Boston, in late 2017. Murakami, who holds a $\mathrm{PhD}$ in nihonga 日本画 (modern Japanese-style painting), had long incorporated lighthearted or satirical references to Japanese art history as part of his appropriation-based artistic strategies.

Together, all the exhibitions mentioned above challenge the old working premise of late nineteenth- and twentieth-century Western modernism, which treated the persistence of "tradition" as a form of conservatism. Yet, as others have noted, the celebration of Japan's successful mastery of modernism while maintaining the authentic elements of Japanese culture is a trope found in both Orientalist and nationalist discourse. ${ }^{8}$ The many expectations supporting "tradition" oblige us to look, once again, at recent developments in the field.

\section{Tradition in a Globalizing Art World}

Even more so than a decade ago, global modernity and contemporary art have come into their own as clearly

8 Weisenfeld, "Reinscribing Tradition"; Weisenfeld, "Publicity and Propaganda"; Yiengpruksawan, Review of Nihonga. 
defined fields of collecting, curation, and display. Experts have expanded their purviews to admit works previously deemed lacking in the ability to "fit with the narrative," a phrase that modern art curatorial staff in Chicago and Los Angeles used circa 2010 when explaining to me why certain pieces, although actively acquired by the museum, had not yet appeared in the exhibition galleries. " "Modern," observed Bruno Latour, is "doubly asymmetrical: it designates a break in the regular passage of time, and it designates a combat in which there are victors and vanquished." ${ }^{\prime \prime}$ In the current museum climate of culturally pluralistic narratives, the concept of tradition has developed in tandem with changes to the definition of modern or contemporary art, which is expanding to accommodate what Latour might describe as new victors.

In a similar vein, historian Dipesh Chakrabarty has suggested that amid the tendency to narrate history in a more trans-regional fashion, modernity has become a prize awarded by the reviewer or historian. Chakrabarty evokes the image of clipboard-wielding historians who vet objects of study from around the globe according to a checklist of laudatory "modern" qualities. As historians introduce this imaginary checklist to an ever-expanding roster of geographical regions and historical moments, says Chakrabarty, a choice emerges: either we can "dilute" the definition of modernity so that it applies more broadly, or we can revert to the earlier model, rooted in Marxism, of deploying modernity as an exclusionary criterion. ${ }^{11}$ Under the latter model, modernity is conferred on some societies and withheld from others who fail to meet the criteria. Understanding that historians will continue to apply and debate the term, Chakrabarty urges scholars to maintain academic precision around the concept of the modern even as they avoid the pitfalls of Western centrism. He cites the words of historian Sheldon Pollock:

There is no doubt that the non-West participated in major ways in the material transformation that marked modernity as a global phenomenon ... [but] it seems that modernity across Asia may have shown simultaneity without symmetry. But should this symmetry turn out to reveal continuity and

9 Foxwell, "Crossings and Dislocations."

10 Latour, We Have Never Been Modern, p. 10.

11 Chakrabarty, "The Muddle of Modernity." not rupture, no need to lament the fact. There is no shame in premodernity. ${ }^{12}$

Chakrabarty lets this statement hit without weighing in on it directly. Is Pollock counseling Asia to be satisfied with its own ostensibly limited modernity? By beginning with the image of undifferentiated "non-Western" parties sharing in the achievement of Western modernism, it would seem that the outcome of his narrative is predetermined. Further, by implying that there are varied but simultaneous discourses of early modernity based on region, this approach would appear to justify the old disciplinary model of each historian remaining tied to his or her geographical area of specialization. This old approach is intellectually limiting and leaves intact the privileged position of the non-"non-West."

Pollock goes on to propose intellectual rupture, the ability to think of the past as something separate from and critically removed from oneself, as a major criterion of modernity. ${ }^{13}$ His thesis also reflects the terms on which members of the Paris-, Berlin-, London-, or New York-based contemporary art world have judged or segregated tradition-based artists, who are mostly from non-Western or indigenous communities located in other parts of the globe and maintain a distance, unintentional or intentional, from the world's most financially and culturally active centers for contemporary art. ${ }^{14}$ The artist Nicholas Galanin (b. 1979), a member of the Northwest Coast Tlingit indigenous population, has called attention to the unspoken assumptions shaping impressions of the type of person who produces "traditional" art. One of Galanin's most frequently exhibited works is White Carver, a piece that puts a white woodworker on view in the galleries to demonstrate traditional whittling techniques (figure 1). The incongruousness of seeing a member of the white EuroAmerican majority population producing wooden handcrafts in an art museum environment compels viewers to revisit their expectations about whose "tradition" is enshrined therein. Many of Galanin's works leverage his status as a contributing member of two

\footnotetext{
12 Pollock, cited in Chakrabarty, "The Muddle of Modernity," p. 671.

13 For evidence and an elaboration of this argument, see Bann, The Clothing of Clio.

14 For an attempt to compile a list of such cities, which, however defined, are by no means confined to the "West" (but which do not, in fact, contain any cities in Japan), see Artsy Editors, "The 15 Most Influential Art Cities of 2015"; see also Gray, "China Has Overtaken the U.K."
} 


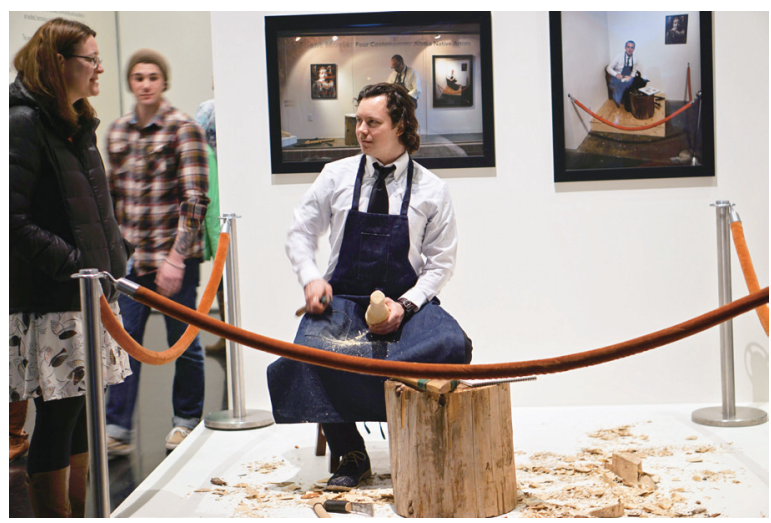

Figure 1. Nicholas Galanin. White Carver. 2016. Mixed media. Photograph courtesy of Nicholas Galanin, with permission to publish.

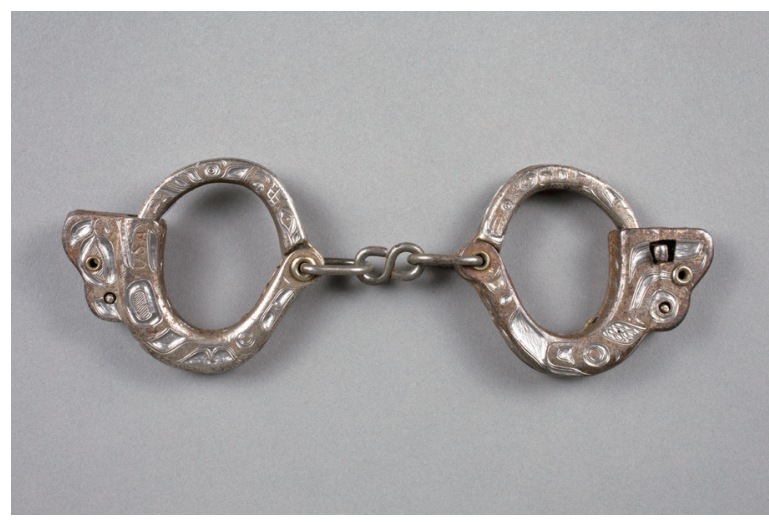

Figure 2. Nicholas Galanin. Indian Children's Bracelets. 2014 Metalwork. Portland Art Museum, accession number 2014.130.1. Reproduced with permission of the artist.

usually separate groups of artists: the producers of Tlingit wood and metal objects, and conceptual artists throughout the globe. His trenchant works, as in Indian Children's Bracelets, a pair of hand-wrought metalwork handcuffs (figure 2), offer strategies relevant to tradition-based artists in Japan and from other locales outside modern art's historic Euro-American center. ${ }^{15}$

Similar to Galanin, the six artists featured in Szostak's Imayo exhibition of contemporary Japanese art embrace and extend materials and techniques transmitted from the past. Like Galanin, their subject matter prompts viewers to do a double-take, either by questioning what viewers are hoping to get out of tradition, or by topicalizing distinctly contemporary issues, as in

15 Fidler, "Stumbling Through a Stony Field." See also Russel, Shapeshifting.
Competitive Society by Ishii Tōru 石井亨 (b. 1981) (figure 3). Ishii's wax-resist Yūzen-dyed silks reflect years of training in carefully transmitted techniques. The designs feature imagery from the Japanese past that has literally been warped. In Competitive Society: Sarariman, Japanese white-collar employees, are inflected with the features of samurai warriors and pixelated and stretched in ways that evoke the use of picture-editing software. In various ways, the other artists in the Imayo exhibition similarly combine technical and sometimes iconographic continuity with thematic or conceptual rupture, thereby creating their own means of both embracing and questioning inherited ideas. This art leaves behind the formalism of late twentieth-century Japanese kōgei 工芸 (craft) and commands the viewer's self-consciousness.

Similarly, Kimura Ryōko's works, also featured in the Imayō exhibition, use detailed, labor-intensive modern nihonga techniques to provoke discussion about the objectification and idealization of women and of agrarian labor that dominated prewar nihonga and are perpetu-

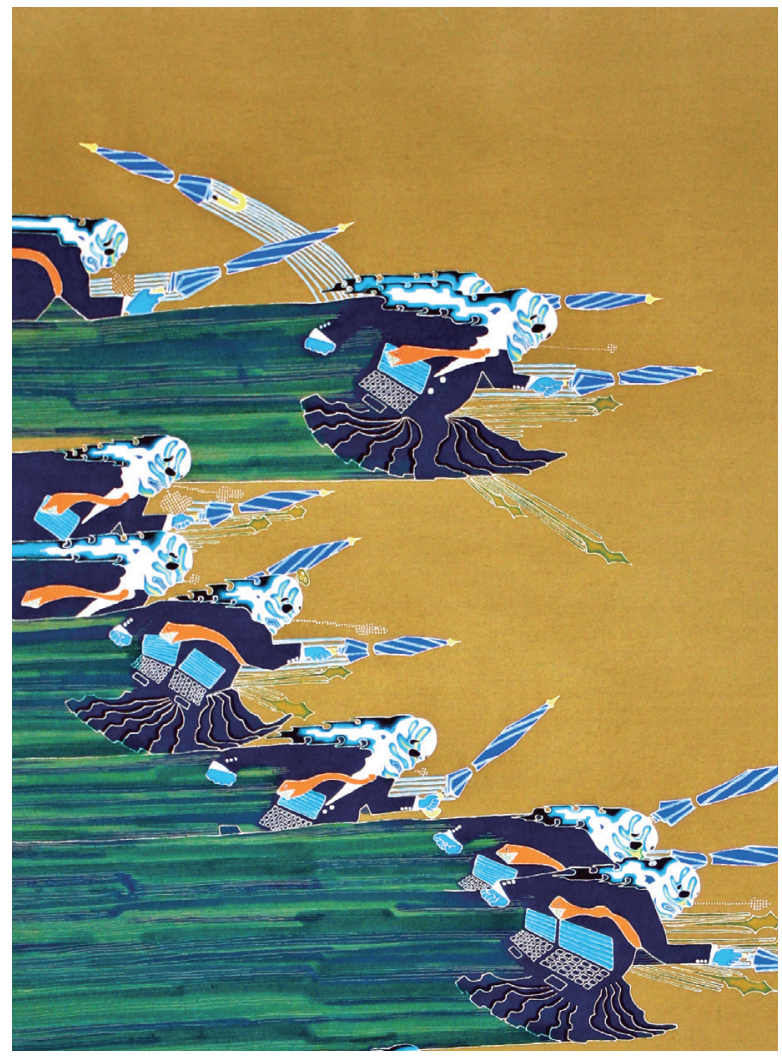

Figure 3. Ishii Tōru. Competitive Society. 2014. Yūzen resist dyed silk. $\mathrm{H} 160 \mathrm{~cm}, W 100 \mathrm{~cm}$. Photograph by Ishii Tōru, with permission to publish. 


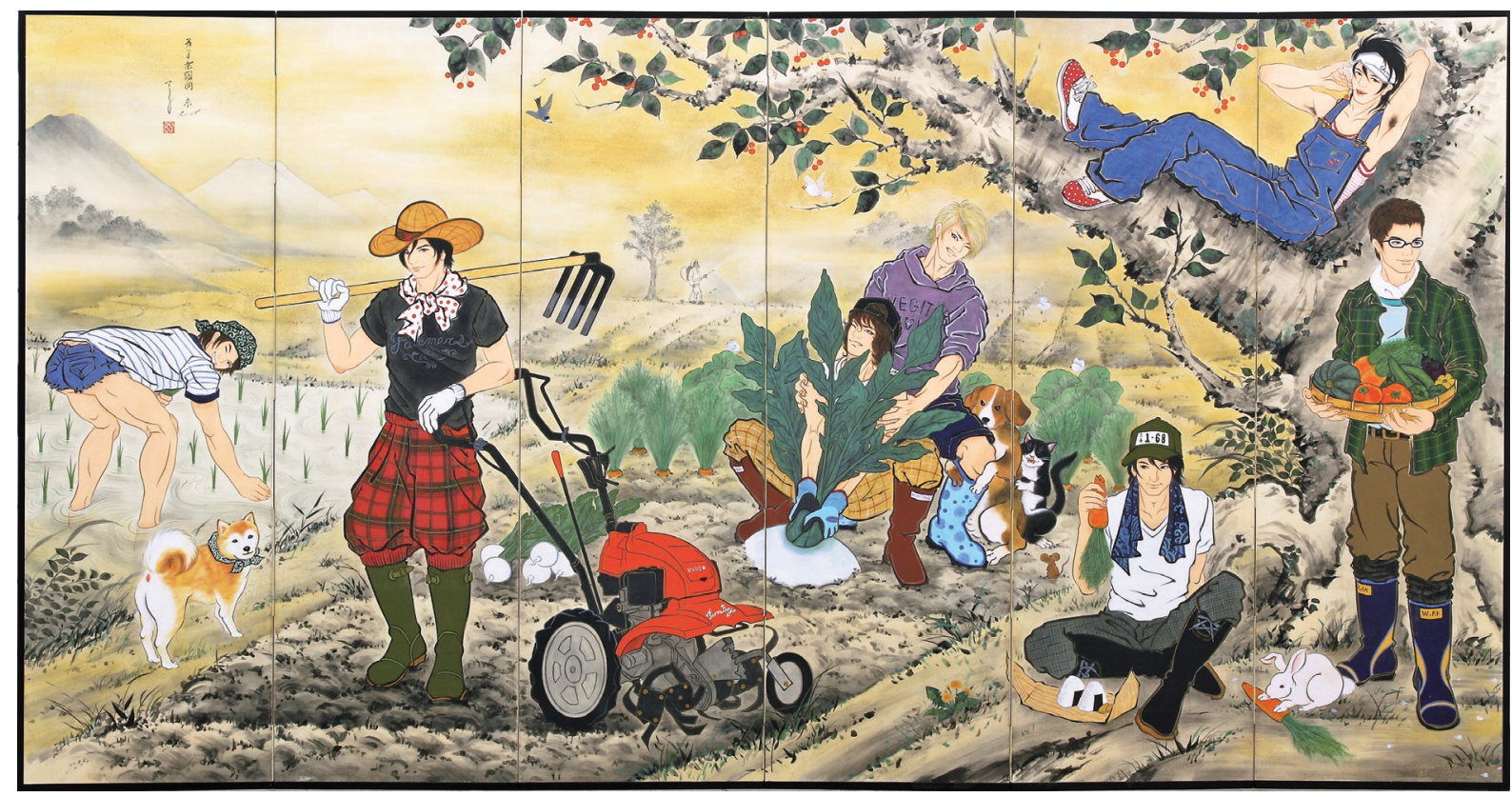

Figure 4. Kimura Ryōko. Boys Paradise: East. 2011. One of a pair of folding screens. Ink, mineral pigments, gold leaf on paper. $\mathrm{H} 207 \mathrm{~cm}, \mathrm{~W}$ $406 \mathrm{~cm}$. Photograph courtesy of Kimura Ryōko, with permission to publish.

ated even today by contemporary nihonga's successful, male-dominated cohort (figure 4). In contrast to contemporary Japanese textile art and pictures of (female) beauties (bijinga 美人画), which maintain continuities with past iconography, functions, and techniques, the works of Ishii, Kimura, and in some cases Galanin accomplish the continuity of technique while breaking with the concepts and functions of past art. Instead of supporting male patriarchal heterosexual desire through bijinga painting, textile production for use as garments, or Tlingit crafts that aid in the objectification of a passive indigenous population, these new tradition-based works address the contemporary art market and perform the type of intellectual rupture that Pollock identifies as modern.

\section{Tradition-Based Art and Social Critique}

The works of Ishii, Kimura, and Galanin combine tradition-based techniques with social critique. In contrast to the suffering and anger embodied in the Indian Children's Bracelet, which represents widespread postwar U.S. policies of removing Native American children from their homes and placing them in foster care, the critique offered by Ishii and Kimura is gentle and presumably causes little discomfort. ${ }^{16}$ Mild as it may seem, however, their venture into social commentary needs to be considered within the roughly century-old history of tradition-based art in Japan.

Ishii and Kimura, among others, represent a new generation of artists post-Murakami Takashi for whom the ironies and potential of cross-cultural marketing and exhibition have always been apparent. Having elected not to enroll in the major Japanese professional organizations for their respective fields, these artists also shoulder a greater share of the burden of securing patrons and exhibition venues. It could even be said that their efforts to define and recruit a worldwide audience for their works shaped the art itself. This can arguably be said of Murakami, who, after moving to New York, began to produce works that indirectly address the question of how foreign audiences understand Japanese art. Cross-cultural understanding of Japan and Japanese art also figure prominently in the work of Tenmyouya Hisashi, whose work arose connected to the art of Japanese tattoos and consequently to ukiyo-e 浮世絵 styles of the shogunal (Edo) era, and to Teraoka Masami, an artist from Hiroshima who attended

16 See, for example, Hearn, Ink Art. 


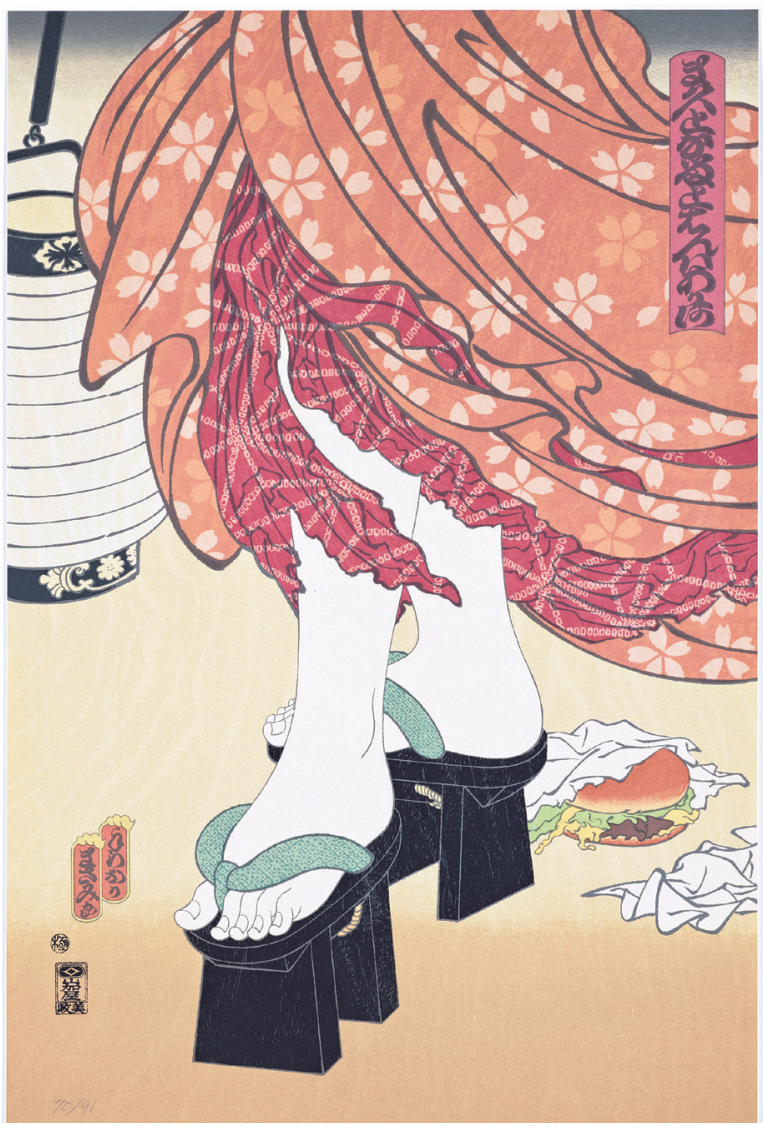

Figure 5. Teraoka Masami. McDonald's Hamburgers Invading Japan: Chōchin-me. 1982. Thirty-six color screenprint. H 54 cm, W $36.4 \mathrm{~cm}$. Fine Arts Museums of San Francisco.

art school in California and later moved to Hawaii. For such artists, playing with references to past art and producing works that are visibly Japanese was intimately related to their own experiences with cultural identity, self-marketing, and expectations from the Euro-American-centered art world of the late twentieth century.

In his New York exhibition Little Boy: Arts of Japan's Exploding Subculture (2005), Murakami held that Japanese otaku おたく (catering to people with obsessive interests) and kawaii 可愛い (cute) subcultures are symptomatic of certain ills or challenges in postwar and contemporary Japanese society. He has also encouraged (Japanese) viewers who have expressed disgust with or hesitation at his works to consider directing those sentiments back toward Japan or to the Japanese art world as a whole: "I'm representing the current situation of Japan. It's proof that I was born and grew up in such a place."17 Murakami entered Tokyo University of the Arts in 1982, well prior to the internet age. Compared to Ishii and Kimura, he represents an earlier phase in the experience of producing Japanese contemporary art, and particularly nihonga, in simultaneity with art in New York. In a 2002 interview with curator Hélène Kelmachter, Murakami looked back on his first residency in New York, describing the misunderstanding and unnecessary seriousness with which the American art world approached his attempts at absurdity and meaninglessness:

When I created the character of Mr. Dob out of that meaningless pun ... I was convinced that I would have no trouble finding a way into the contemporary art scene in the U.S. I thought I'd be recognized as a Japanese "slapstick artist" who made absurd puns ... but I soon realized that this stuff didn't work over there at all ... art world people over there listened to it all very seriously, all the more so since it was formulated in Japanese. And so I gave up using the character of Mr. Dob over there.... But I found myself thinking more and more about my cultural background. ${ }^{18}$

Murakami describes the trial-and-error process by which he began to produce and present art that would reach English- or French-speaking audiences, all the while coming to new conclusions about his cultural identity and the animation and manga that had captivated him in the 1970 s and 1980s. Murakami's New York exhibition Little Boy: Arts of Japan's Exploding Subculture should likewise be read in light of the artist's experiences in New York. "What I am trying to create is neither commercially acceptable nor sustainable in Japan," he said in his 2000 interview with Mako Wakasa. He speculated that non-Japanese, on the other hand, "listen to me" with a sort of anthropological fascination, "because they want to understand" contemporary Japan and otaku culture. ${ }^{19}$

When Murakami produced his $\mathrm{PhD}$ thesis on $n i$ honga in 1993, he was already making use of his initial brief experience in New York to gain a fresh perspective on the place of Japanese art, and particularly of nihonga

17 Wakasa, "Interview with Takashi Murakami."

18 Kelmachter, "Interview with Takashi Murakami."

19 Wakasa, "Interview with Takashi Murakami." 
(his own area of specialization) in the international art world..$^{20}$ Perhaps not since 1904, when Yokoyama Taikan 横山大観 (1868-1958) and Hishida Shunsō 菱 田春草 (1874-1911) gained a positive reception in New York and Boston with their tonalist works, had nihonga artists seriously considered making their main audience outside Japan.

When viewing the paintings of Kimura or the woodblock-print-style works of Tenmyouya Hisashi, it is relevant to recall the mid-1970s screen prints of Teraoka Masami, which juxtaposed images of traditional Japanese culture in a ukiyo-e style with the logos and products of McDonald's, then spreading rapidly in Japan (figure 5). Further, while Teraoka's works provoke reflection on and possibly critique of globalization, the direct juxtaposition of a visibly "traditional" Japanese ukiyo-e mode and an icon of American-born fast food ensured that his prints themselves became easily consumable global commodities that required almost no cultural interpretation.

Today, the market for nihonga within Japan has contracted, while the ease of circulating images and people worldwide has led to an unprecedented degree of simultaneity. Just because images and people can travel, however, does not mean that the same work of contemporary art is equally legible in all places. Within this reality, and under the pressure of self-marketing, certain artists naturally experiment with the channels of communication.

As they address the expectations of diverse international and Japanese audiences, artists such as Kimura and Ishii have developed certain shared characteristics. Their work produced for Imayō is, first, visually Japanese in appearance; second, a source of minimally offensive social critique and intellectual stimulation; and third, demonstrative of inherited craft techniques demanding intense labor and skill. Further, as the artist Aida Makoto 会田誠 (b. 1965) discovered in the course of satirizing the bijinga and sensogga 戦争画 (war propaganda paintings) genres, paintings "of girls" (onna no ko 女の子)-attractive or sexualized girls — sell well. We might call this the libidinal plus-alpha, and it appears in Kimura's works, albeit with the added benefit of upending gender stereotypes: drawing on the legitimacy of early modern Japanese erotica (shunga 春画) and erotic contemporary Japanese fan fiction, Kimura's

20 Murakami, Little Boy. more explicitly sexualized images of beautiful young men (bidanshi 美男子) (not shown in the Imayō exhibition) literally address an undersupply in the modern and contemporary high art market, which was long focused on images of beautiful women. ${ }^{21}$

In this way, the smartly critical and visually Japanese works of the Imayo artists fit a certain model of contemporary artists who critically engage with "tradition" around the globe. Yet Szostak relates that Ishii, Kimura, and the other Imayo artists considered themselves outliers who had difficulty finding their place in the Japanese art world. ${ }^{22}$ Murakami and Aida's success notwithstanding, critically and intellectually ambitious work was not common among artists of nihonga and $k \bar{g}$ ei; these artists typically devoted a decade or more of their lives to mastering techniques transmitted from the past, and their artistic activities are closely monitored by professional organizations such as Nitten 日展, the Japan Art Institute (Nihon Bijutsuin 日本美術院), or the Japan Kōgei Association (Nihon Kōgeikai 日本工 芸会). In exchange for controlling supply and pricing and providing access to patrons, these professional organizations have enforced a respectful, apolitical stance toward artistic production and society as a whole. The seniority system on which they are based, moreover, arguably runs counter to the premise of modernism, which has historically entailed irreverence toward (or revolt against) the senior generation. The rhetoric of respect established by artists' professional organizations is couched in terms of respect for time-honored techniques, for the senior artists who have carried on the trade, and for the patrons of traditional craft wares. This generalized atmosphere of respect, however, tacitly extends to encompass the personal lives and actions of the member artists, making it difficult for them to engage in activism or critique. Consequently, tradition-based craft and painting had also established a legacy of formalism that refrains from commentary on current events.

Despite an official commitment to Japanese techniques and materials from the past, the mainstream craft objects and nihonga of the professional organizations are in many ways distant from the techniques, subject matter, and functions of past art. ${ }^{23}$ As an ex-

\footnotetext{
21 Aida et al., Makoto Aida: Cynic in the Playground.

22 Szostak, personal communication, November 2016.

23 Foxwell, "The Painting of Sadness?"; Furuta, Nihonga to wa nan datta no ka; Kitazawa, "Rettō" no kaiga.
} 
ample, we can turn to Murakami Yūji 村上裕二 (b. 1964), the younger brother of Murakami Takashi. In contrast to the elder Murakami's youthful antipathy toward nihonga as an artistic and pedagogical institution, Murakami Yūji became a prize-winning member of the Japan Art Institute, the group that had been founded by Okakura Kakuzō 岡倉覚三 (1862-1913) in the Meiji period in order to raise the profile of tradition-based modern Japanese painting. The younger Murakami's painting Kazeiro 風色 (The Color of the Wind, 1996, ink and mineral pigments on board) represents the features of twentieth-century nihonga that the well-funded and seniority-based Japan Art Institute maintained across decades through its carefully selected juries. ${ }^{24}$ Murakami Yūji applied intense mineral pigments and ink washes based on transmitted methods, while the painting's compositional framework and draftsmanship adhere to European standards. The use of a bird's-eye perspective to skew the picture surface toward the ground plane might allude to East Asian art, but the painting's spatial logic is European, and it does not necessarily depict Japan. The work's serenity and its lack of strong movements or emotions are deeply familiar within the genre of nihonga painting. ${ }^{25}$

In a sentiment that echoes Galanin's frustration with the limits observed by Tlingit artists today, Murakami Takashi wrote with exasperation in 1993 that most of his classmates seemingly never even bothered to reflect on the definition of nihonga or on what they, as artists in the present day, were trying to achieve through their careers. ${ }^{26}$ But here, I would argue, Murakami Takashi's youthful critique of nihonga's limits is only part of the story. We must entertain the possibility that artists like Murakami Yūji or countless others were not remiss when it came to thinking critically about what they were doing; rather, bolstered by membership in professional organizations and the attendant networks of teachers, students, and patrons, their works represent a conscious choice to eschew the deep-seated cynicism, self-awareness, and social critique that we have come to expect from the Imayō artists or from Murakami Takashi. The conscious choice to avoid contentious or unsettling topics despite their high level of repute among critics and curators worldwide might also be

\footnotetext{
24 "Murakami Yūji," Taigadō. http://www.masacor.com/taigado/ murakami.html.

25 Foxwell, "The Painting of Sadness?"

26 Foxwell, "The Total Work of Art."
}

related to what scholars such as Kitazawa Noriaki, Satō Dōshin, Adachi Gen, and Mori Hitoshi have linked, in discussions of both art and craft, to the unhappy history of bijutsu 美術, the formal concept and system of the fine arts that was imposed through government arts policy in a top-down fashion. In the process of imposing bijutsu, officials marginalized koggei and effectively blocked the avant-garde by refusing to provide a platform for art that flouted conservative expectations of political, social, and moral propriety. ${ }^{27}$ From the Meiji period through the post-bubble era, the Japanese government's outlay of funding and institutional planning for the fine arts was guided by the expectation that artists would edify the public and support a positive image of Japan on the world stage rather than highlighting problems in Japanese society, history, or politics. This is a tradition that goes back to the Meiji period. In this sense, I would like to suggest that the reposeful formalism and other predominant visual qualities in tradition-based contemporary art cannot be fully ascribed to a lack of self-examination. They also reflect the will to create something else: a third thing that is neither the heavily policed, public realm of bijutsu, nor the unsettling, intellectually demanding world of critically ambitious contemporary art. In positive terms, this third thing might be expressed as a work that constructs and engulfs the viewer in a harmonious, meditative environment encouraging the suspension rather than the activation of critical self-consciousness. This type of work can be termed immersive.

\section{Patronage and the Immersive Art Environment}

Modernist art has repeatedly sought to surround and absorb the viewer in an immersive environment that represents, at times, the dissolution of boundaries between art and life; and at times has asked viewers to reflect on modes of attention, display, and interaction between a work and themselves. ${ }^{28}$ From the philosophy and studio environment of Piet Mondrian's Neo-Plasticism in the 1920 s to Kurt Schwitters' Merzbau of the

27 Kitazawa, Me no shinden; Satō, Modern Japanese Art; Adachi, Zen'ei no idenshi; Mori, Nihon 'kōgei' no kindai; Kitazawa, "The Genesis of the Kōgei (Craft) Genre."

28 See the discussion of modern display modes in Sutton, The Experience Machine, pp. $147 \mathrm{ff}$. 
1930s, Stan VanDerBeek's Movie-Drome of the late 1960 , and James Turrell's "skyspaces" of the 1970 s onward, inhabitable, immersive works have a long history in modernism and need not be associated with the suspension of judgment and criticality; indeed, a work like the Movie-Drome was designed to activate the spectator through the simultaneous and open-ended presentation of multiple images and image types which could not be reconciled or resolved into a single thesis. ${ }^{29}$

Even so, modernism's endorsement of classical, restrained, and contemplative viewing environments and universal concepts has at times migrated to the realm of generalized spirituality or actual religious devotion. Often, this migration occurs through patronage and public audiences, as with the overwhelming success of the concrete Church of the Light (1989) by Andō Tadao 安藤忠雄 (b. 1941), or, as art historian Anna Chave has observed, with the Dia Foundation's extensive support of American Minimalist art. Chave has pointed out the extent to which the Minimalists' most prominent patrons, Heiner and Fariha Friedrich, who founded the Dia Foundation, "[employ] words like holiness, truth, clarity, beauty and inspiration" when discussing landbased art and other sites to which visitors can journey to view Minimalist art. ${ }^{30}$

In Japan, where the art market is much smaller and artists even more susceptible to pressures from influential patrons or sponsors, the migration of modernist self-referentiality into the zone of spiritualism has occurred with some regularity and arguably has its roots in prewar patronage, which was heavily patterned on tea gatherings (chanoyu 茶の湯; the tea ceremony). The Japanese art collector and entrepreneur Fukutake Sōichirō 福武總一郎 (b. 1945), who conceived and funded the art museums on Naoshima, showed a longing to create spiritually uplifting spaces of modern and contemporary art; like the Friedrichs, he patronized the American West Coast artist Walter de Maria (19352013) and invited him to design site-specific works for his museums. In this sense, Chave might as well have included Fukutake when she wrote, "the Minimalists' primary patrons successfully ensured a fuller development of a spiritualized and epic chapter to the Minimalist story than would otherwise have been possible." ${ }^{11}$

\footnotetext{
29 On the genesis of the modern spectator and modes of attention, see Crary, Techniques of the Observer.

30 Chave, "Revaluing Minimalism," p. 474

31 Ibid., pp. 479-80.
}

The fact that patrons, when purchasing contemporary art, might also be seeking to purchase a source of spiritual or somatic regulation has been downplayed or indirectly criticized in the discourse on contemporary art. This is likely due, as media historian Paul Roquet has noted, "to the resistance toward mood found in much twentieth-century modernism." ${ }^{22}$ By contrast, notes Roquet, "in 1980s Japan, people began using a wide range of media with the specific aim of mood regulation," including background music and ambient music. The turn to music, art installation, and digitally altered environments in order to achieve solace and spiritual equilibrium also relates to what architectural historian Jonathan Reynolds has described as "the relentless pursuit of a cultural 'lost home' in modern urban Japanese visual culture since the 1940s." 33 No longer embodied in an inhabitable physical structure from the past, the allegorical home, the space of inner peace and belonging, needed to be recreated through architecture, art installation, poetry, and other media, which collectively gave rise to the image of the Tokyo urban nomad, someone whose place of rest was ideally a mobile, sparse, and capsule-like resting place for the physical and somatic self, "small, self-contained modules that provided minimal shelter from their urban environment." 34 Even as modern and contemporary artists and art critics emphasized the autonomy of the work and its maker, patrons and viewers saw themselves as purchasing or accessing an experience that would have a positive effect on their lived reality.

The attentiveness of modern Japanese art collectors to mood and to the construction of a mood-regulating environment through art, architecture, and garden design has strong prewar antecedents. The late medieval to early modern Japanese teahouse (cha'an 茶庵), and the experience of the tea gathering generally, was a focal point of most major private art collectors from the Meiji era onward. ${ }^{35}$ The teahouse was at once a compact art exhibition space and a building small and intricate enough to be treated and collected like an object; at the same time, it served as an antidote to the "displayism" of modern museum and gallery spaces through its functional engagement of three-dimensional objects and visitors. Finally, given its close relation to Zen

\footnotetext{
32 Roquet, Ambient Media, p. 16.

33 Reynolds, Allegories of Time and Space, p. 189.

34 Ibid., p. 189.

35 Guth, Art, Tea, and Industry.
} 
practice, the teahouse was, unabashedly, a spiritual refuge. As such, tea practice was, quite literally, an instant sell for the industrialist art collectors and founders of Japan's first private museums. The teahouse also represented the fusion of traditional crafts, modernist aesthetics, and spirituality: what Okakura Kakuzō interpreted as "teaism" to English-speaking audiences as early as $1906 .{ }^{36}$

While Japanese tea practice is brimming with ethnic particularity, it also served as an antidote to the ethnic particularism that threatened to dominate discussions of tradition-based artistic production in the mid-twentieth century. In postwar Japan, the faith healer Okada Mokichi 岡田茂吉 (1882-1955), founder of the MOA Museum of Art in Atami, openly named art, tea, care for the environment, and the commitment to organic farming as essential accompaniments to spiritual devotion. Okada's vision, like Fukutake's, was universal and nationless, addressing believers and art audiences across Asia and the world even while committing to support the continuation of tradition-based Japanese arts and crafts, and the overall environmental, spiritual, and financial health of the Japanese countryside.

The cosmopolitan patronage of Okada or Fukutake accommodated tradition-based works among the patronage of other types of art. Okada supported tradition-based contemporary craft. Fukutake was a supporter of artist Lee Ufan 李禹煥 (b. 1936), whose From Line and From Point series, although sometimes referencing ink techniques or incorporating Asian mineral pigments, "owe[d] no debt to the incorporation of symbols or signs whose meanings are derived and perpetuated by the world outside of the painting. ${ }^{\prime 37}$ Lee's work represented, in the words of Joan Kee, "a desire for freedom" from cooptation as an agent of the modern, ethnically based nation-state..$^{8}$ But the key comes in understanding that these relationships are not fully reciprocal: while the collecting philosophy of a patron such as Fukutake or the Friedrichs can embrace Lee Ufan or Donald Judd, these artists, working autonomously to explore visual ideas through their work, typically resisted cooptation by spirituality, the objectives of a powerful patron, or other manifestations of "the world outside of the painting."

36 Okakura, The Book of Tea.
37 Kee, "Points, Lines," p. 418.

38 Ibid.
In sum, prevailing scholarship casts a jaundiced eye toward idealist collectors who attempt to situate abstract and contemporary art within a transcendent, immersive space, but this form of patronage had been well established in Japan since the prewar era, when wealthy collectors designed private art museums for their collections, sometimes on the grounds of their own former estates, to be complemented by a strolling garden and the culture and architecture of tea gatherings. ${ }^{39}$ Though art historians like Chave call attention to tension between the work of art's individual project and the collector's broader designs toward spiritualism, the transcendent, immersive aesthetic is both prominent and historically grounded within Japanese contemporary art.

\section{From Criticality Toward Transcendence}

This section considers a number of recent works, whether serious or lighthearted in nature, that focus on what Roquet has described as the "mediated provision of calm," and seem to entail the alleviation from psychological strain, accompanied by the suspension or allaying of aggressive criticality and self-consciousness. The Tokyo-based group teamLab is key to thinking about the prominence of ambient and transcendent aesthetics in the art world and their long-standing relationship both to tradition-based contemporary art and to decades-old Japanese patterns of private collecting and aesthetic appreciation. In the work featured in their 2016 Japan Society New York exhibition, the teamLab programmers and artists used interactive digital panels to engage and extend premodern Japanese visual and spatial concepts and in some cases even recreate specific masterpieces of past Japanese art. As the ultimate expression of the postmodern state of the arts, in which many top art and music school graduates secure jobs in the world of video game design, teamLab was originally not beholden to any institutional expectation that their work function as gallery art; in Seoul, their exhibit can be found within the theme park Lotte World; with the support of Mori Building Co., Ltd., they recently installed teamLab Borderless, a multi-room exhibition

39 Such museums include Seikadō Bunko in Tokyo (f. 1924), Nezu in Tokyo (f. 1941), Yamato Bunkakan in Nara (f. 1946), and Dai Tōkyū Bunko (f. 1949). 


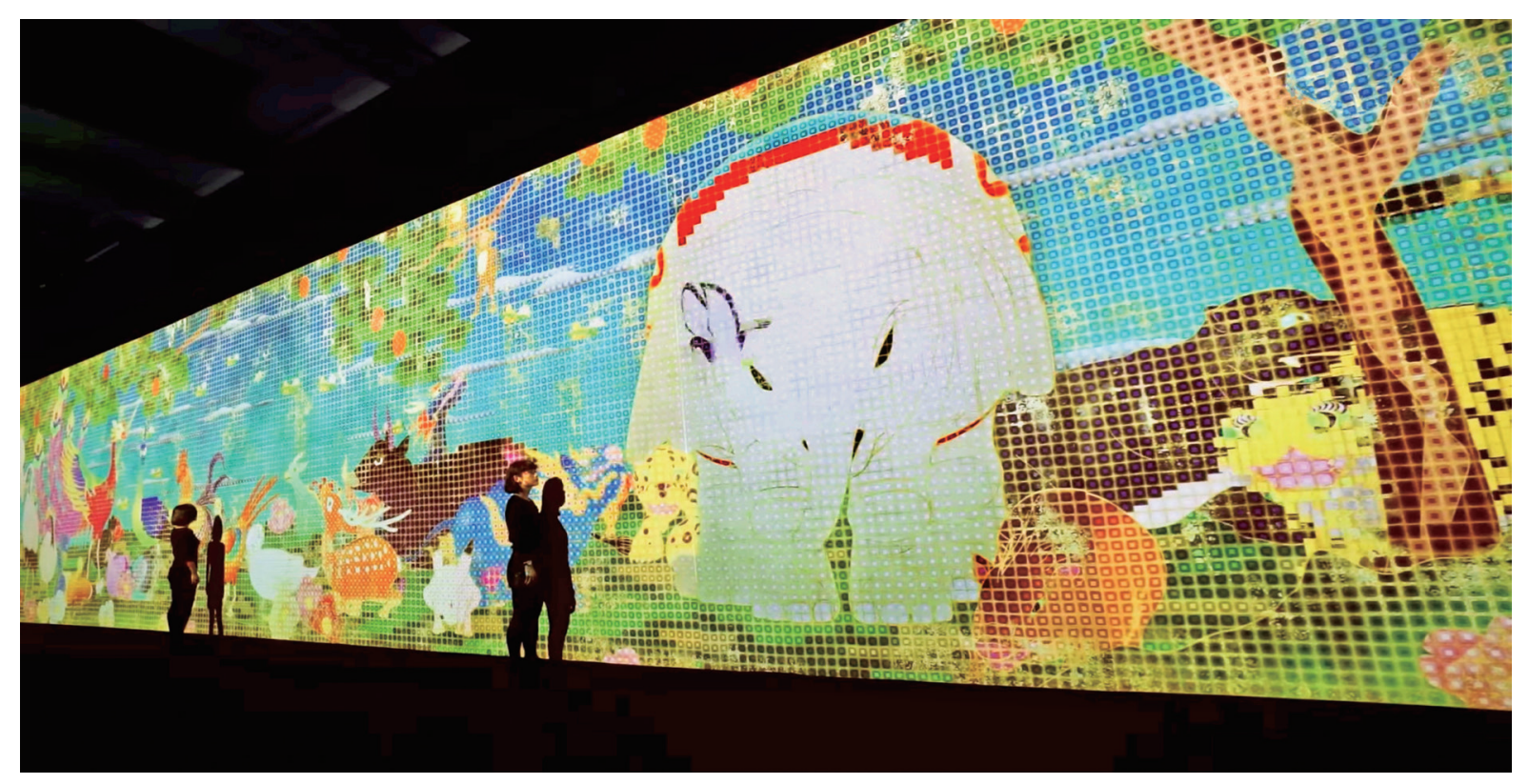

Figure 6. teamLab. Nirvana. 2013. Digital work, 8 channels, 6 min. 20 sec. (loop). Website: https://www.teamlab.art/w/nirvana. Photograph courtesy of teamLab, with permission to publish.

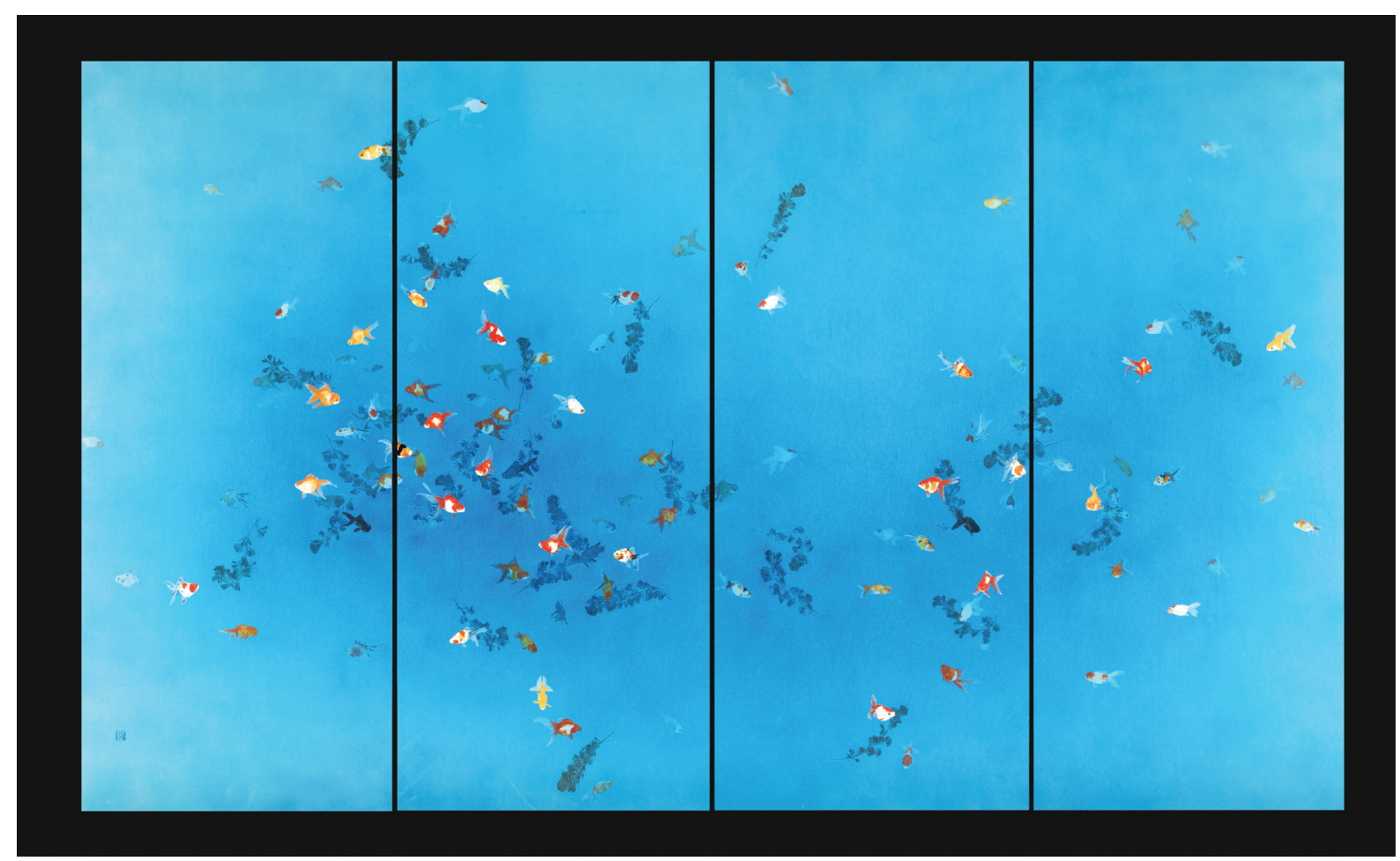

Figure 7. Kambe Tomoyuki. Wish Upon a Star (Hoshi ni negai o). 2010. Ink, mineral pigments, gold leaf on paper. Photograph courtesy of Kambe Tomoyuki, with permission to publish. 
within the entirety of Mori's newly constructed Digital Art Museum, which is located, together with Madame Tussauds, on the attraction-laden strip of Odaiba. The work of teamLab and the enthusiasm it inspires are a prime example of an absorptive or transcendent mode in tradition-based contemporary Japanese art, a mode that is unconcerned with preserving contemporary art's aura of exclusivity and erodes the boundary between art and attraction.

The work of teamLab at the 2016 Japan Society exhibition made strong use of tradition-based iconography. In its recreation of a screen of a pair of animals by the eighteenth-century Japanese master Itō Jakuchū 伊藤若冲 (1716-180o), teamLab upped the color spectrum to fuchsia and lime green, rendered the animals in slightly more rounded forms and cuter expressions, and programmed the image so that the animals moved, breathed, and gently responded to the viewer's presence (figure 6). Viewers were enthralled as an eighteenth-century image of a paradise garden literally fluttered and breathed before them. The work does not demand historical context or critical analysis: rather, it exudes a quiet, gentle presence by simply existing in its marvelous way and allowing the viewer in turn to exist.

Another contemporary artist whose work embraces this absorptive, transcendent, spatially and temporally unbounded approach is the nihonga artist Kambe Tomoyuki, who, similar to the artists featured in Imayo, remains deliberately unaffiliated with Japan's powerful nihonga associations. Kambe exhibits in Japan and abroad through the Gallery Hirota Bijutsu. His large, multi-panel Wish Upon a Star, exhibited in the Okakura Tenshin Memorial Museum in Izura in 2010, is a temporally and spatially unbounded large-scale picture surface with goldfish rendered in mineral pigments, gold foil, and a translucent Japanese paint (figure 7).

The artist controlled the intensity of the glinting gold foil through exterior applications of translucent Japanese paper or powdered mineral pigments. Functioning as an experience rather than an object of scrutiny, the painting engulfs viewers like a massive aquarium or like a colossal color field painting..$^{40}$ After the work was installed, the artist led local children in the production of small goldfish out of pliable Japanese paper that were then suspended in the corridor where the work hung, illuminated by the natural light pouring in from floor- to-ceiling glass windows. This summertime community art project converted the work from a painting to an installation, heightening the phenomenological experience of being engulfed by the work and suspended peacefully into what the artist calls its "innocent world." In interviews, Kambe has repeatedly expressed the importance of involving the community and introducing children to age-old Japanese materials like washi 和 紙 paper, ink, and gold foil. For him, the extension of the work from the second to the third dimension was specifically also the extension of the art and of nihonga techniques outward into the community, and onward to the next generation.

Kambe's goldfish belong to a set of works exhibited under the title Innocent World, and are precisely the commitment to "innocence" that might be seen as the artist's critical contribution, however modest it may seem. This tendency, which he has no desire to abandon, also seals the artist's fate as someone who would always function in the domain of tradition-based contemporary art and never in the realm of contemporary art at large. Kambe is not ambitiously conceptual, or at least not in the vein of contemporary art usually featured at major global art biennials. His choice to exist apart from such status markers in the world of contemporary art was actually never a problem for him, or for countless top-tier nihonga artists before him. These artists, who command a relatively rare set of skills in the application of ground mineral pigments, were in such demand within Japan, where they also served as teachers, that it did not matter whether they had achieved recognition outside Japan so long as they remained in their métier.

While some may question whether the avoidance of criticism could really be a critical position, Kambe's unwavering commitment to "innocence" is in any case not naïve. Kambe has emphasized that his own time is far from the nihonga heyday of the 1970s and 1980s, much less the 1920s or 1930s, when glittering, technically refined surfaces presented tranquil, temporally and spatially unbounded scenery, flowers, animals, and beautiful women to audiences that the late John Rosenfield described as hushed and reverent. ${ }^{41}$ In Japan's bubble years, relates Kambe, top-tier nihonga artists lived comfortably, even lavishly, supported by income from wealthy and sometimes reclusive private patrons. 


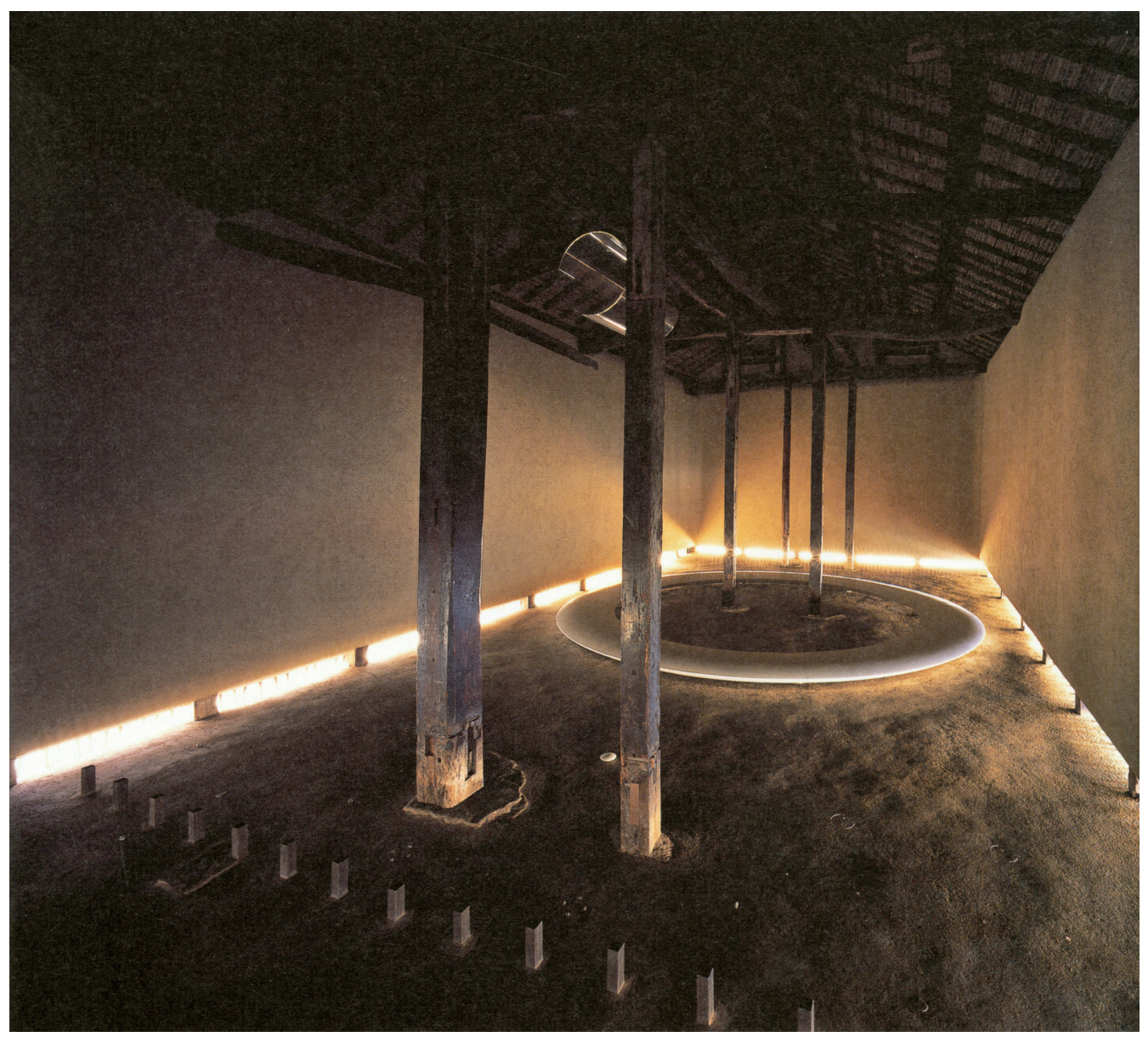

Figure 8. Naitō Rei. Kinza (Being Given). 2001. Installation. Naoshima Art House Project. Photograph courtesy of Benesse/Naoshima Art House Project, with permission to publish.

Today, he notes that few professional nihonga painters can survive without a teaching position, even as they face continual pressure, often through their own Japanese dealers, to exhibit abroad, not only in America and Europe, but also in Hong Kong, Singapore, Beijing, and Taiwan. The shrinkage of the market in Japan and nihonga's limited currency beyond the nation's borders makes us question the extent to which nihonga can continue to live in its own "innocent world," unconcerned with the critical trends and concerns of global contemporary art.

The overwhelming success of teamLab helps to contextualize the significance of Kambe's innocent world to an increasingly globally synchronized art market. At some point, when even criticality, self-consciousness, and cynicism become routine and universally distributed throughout the globe, just like McDonald's and the work of Teraoka or of Murakami Takashi, the creation of a transcendent space in which time and criticality are suspended might itself be an art historically informed and critical gesture. For example, teamLab forges a connection with viewers by adopting the sentimental, idealized, and sensorily immersive environment of the Japanese role-playing video game, or RPG. On the islands of Teshima and Naoshima and in global venues, the artist Naitō Rei 内藤礼 (b. 1961) created installations such as Being Given (Kinzaきんざ, 2001) or Matrix (Bokei 母型, 2010) where the critical contribution centers around transcendence and the suspension of the viewer in a space that offers womb-like insulation from the everyday (figure 8). These are works with the highest level of visual and conceptual ambition, but ones that banish cynicism, aggression, and self-consciousness, instead fostering a durational, meditative 


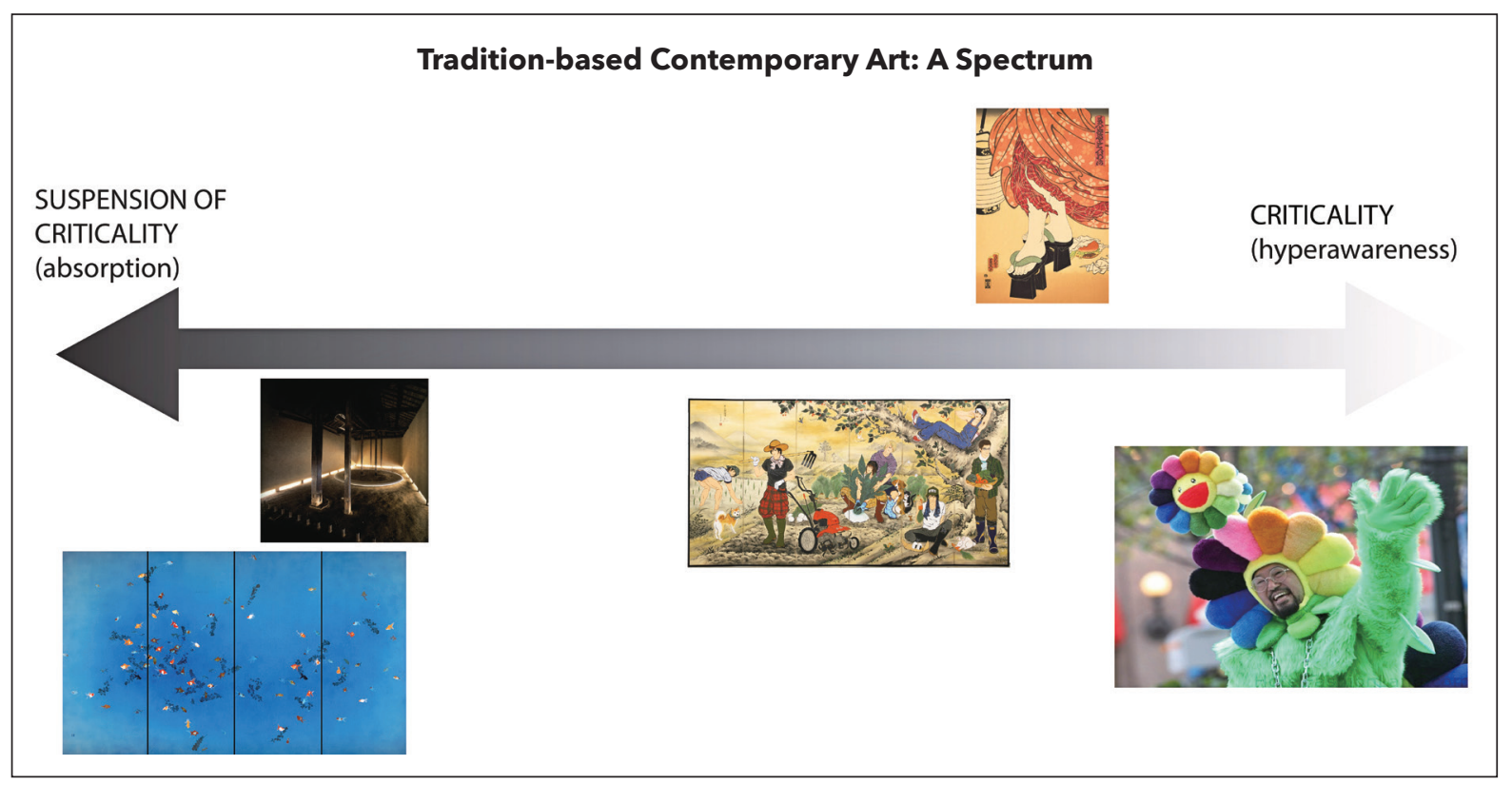

Figure 9. Image by author.

experience whose foothold in the global contemporary art world can be traced back to the earlier border- and disciplinary-crossing boundaries of artists like VanDerBeek or John Cage. ${ }^{42}$ Further, as we can see with both Naitō and her architectural collaborator, Nishizawa Ryūe 西沢立衛 (b. 1966), a yielding, nurturing stance toward environment, materials, and the past is often conceived by the creators as persisting in spite of trends initiated by forces that are more male-dominated and corporate.

Tradition-based contemporary art has been criticized for being overly precious, uncritical, or self-Orientalizing, but I am proposing that some notable tradition-based contemporary Japanese art makes a self-conscious critical stance out of banishing cynicism and self-conscious criticality. This stance holds that there are things in need of our protection, our support, and our belief. These include the environment, rural communities, traditional craft and theater techniques, voiceless people in disadvantaged situations, and, most fundamentally, contemporary beings' own capacity to trust and believe. In advocating for the visibility and continued viability of craft and performance techniques

42 Sutton, "Stan VanDerBeek's Movie-Drome"; Martin, "The Asian Factor in John Cage's Aesthetics." that have been transmitted in Japan for centuries, some tradition-based contemporary art will likely find itself in the position of thematizing its own endangered survival in a fast-paced, aggressively for-profit world, and doing so as a critical and intellectual component of the work.

\section{A Spectrum}

Art that queries the fate of Japanese tradition in a globalizing world becomes monotonous after a pointjust like too many French fries. It is partly for this that we might today be witnessing the rise of an anti-critical critical turn; that is, the measured strategies of certain artists to repudiate self-consciousness in order to redirect viewer attention, create a transcendent environment, and change the tone of reception around tradition-based art. Such works fit with Roquet's definition of ambient media: "Unlike more purely utilitarian forms of 'healing' media, ambient works open up spaces within the overall calm to register a wider range of uncertainty, even anxiety." 43 This stance can be critical because, to quote Roquet, in contrast to "more

43 Roquet, Ambient Media, p. 18 


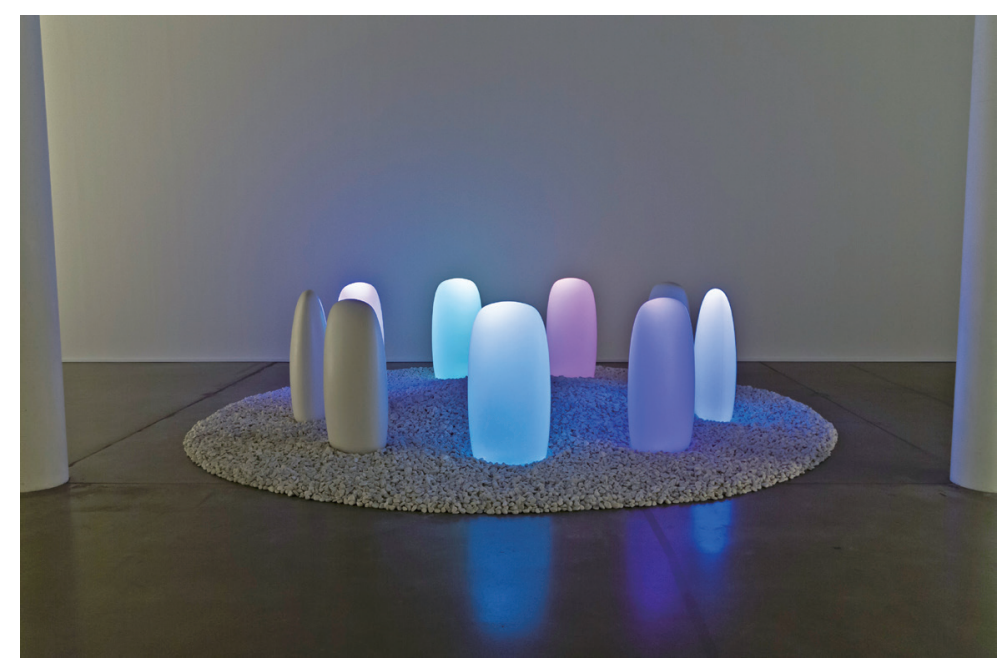

Figure 10. Mori Mariko. Transcircle 1.1. 2004. Glass, light-emitting diodes, stones, computer. Photograph by Ole Hein Pedersen provided courtesy of Mori Mariko; Sean Kelly, New York; and SCAl the Bathhouse, with permission to publish.

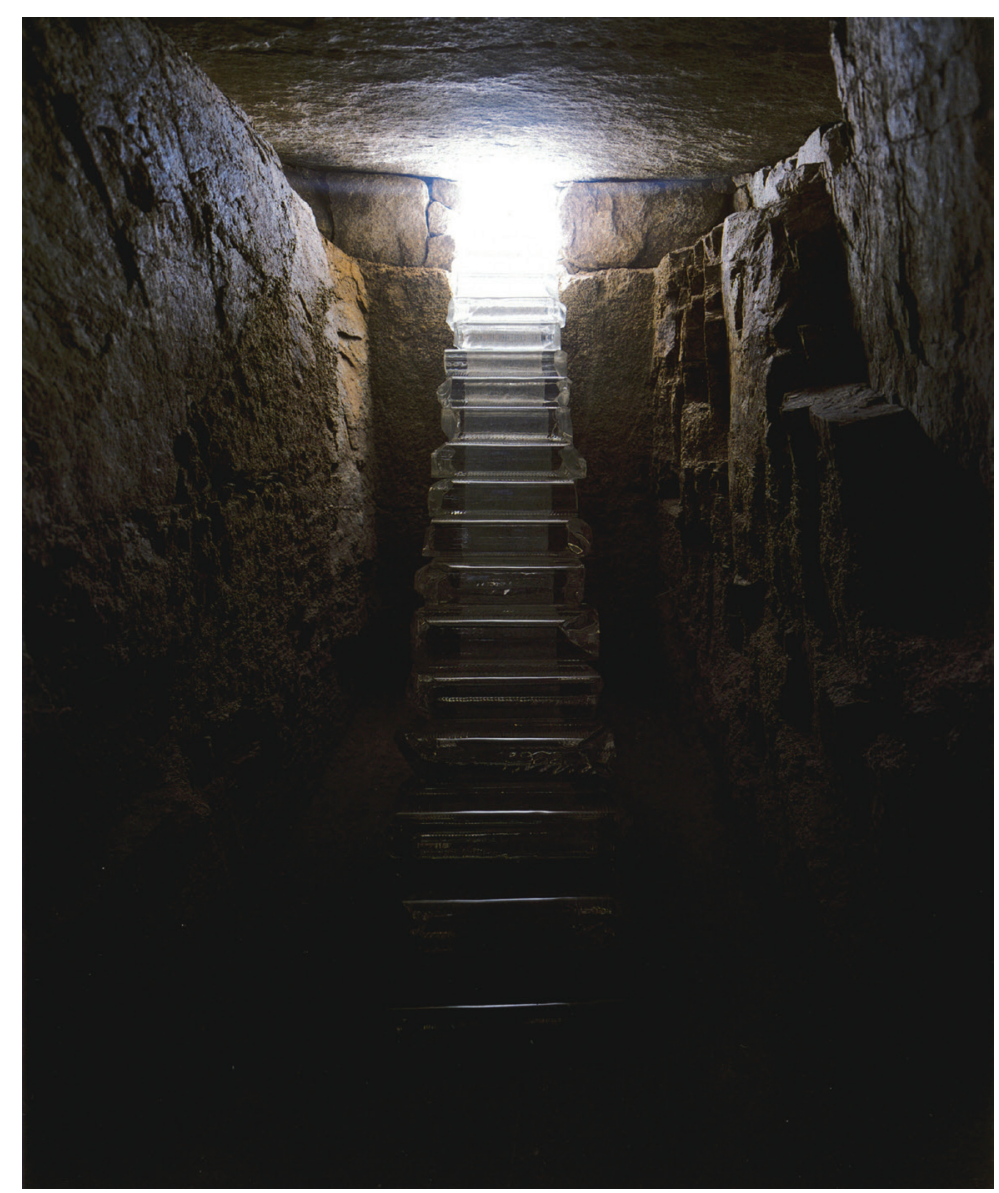

Figure 11. Sugimoto Hiroshi. Appropriate Proportion (Go'o Shrine). 2002. Naoshima Art House Project. Photograph courtesy of Benesse/ Naoshima Art House Project, with permission to publish. 
straightforward 'new age' or 'healing' genres, ambient media hint that therapy culture's mediated provision of calm may ultimately be a fragile cover for larger social landscapes that are anything but relaxing. ${ }^{44}$ Just as a commuter with earbuds or a smartphone can still respond to contingencies of the commute and thus simultaneously occupy two sensory worlds, ambient media and immersive artworks impart a calm or uplifting sensory experience without fully cancelling out the surrounding reality; stopping short of pure escapism, they highlight the strategies of escape, mood management, and self-care in which we periodically indulge in order to cope with the demands of daily life. In visual art, ambient, immersive works today have a strong affinity with or debt to works by Kusama Yayoi 草間彌生 (b. 1929), such as Narcissus Garden (1966-present) or Infinity Mirror Rooms (1965-present), and in particular the lyrical Aftermath of Obliteration of Eternity (2009) and similar installations.

I propose a spectrum to understand the critical investments of contemporary Japanese art and of tradition-based contemporary art (figure 9). These poles diverge at the very point where, for anthropologist James-Henry Holland II, ritual diverges from theater. Holland points out that in theater, "the creativity of the individual performer is highlighted, and a critical viewing ... by the audience is encouraged." ${ }^{45}$ By contrast, he notes that it is meaningless to attempt a performance critique, in this sense, of a religious ritual. Practitioners can invite an outsider to observe the ritual without necessarily believing, but critique is not an available option. Moving beyond tradition-based art to contemporary Japanese art at large, it is apparent that Japanese artists since the 1990s have explored the absorptive power of ritual, which stretches the boundary between "appreciation" and "belief." Examples range from Mori Mariko, who interrogates contemporary spirituality in Transcircle 1.1. (2004) (figure 10) to Sugimoto Hiroshi 杉本博司 (b. 1948), who stretches the boundary between architectural and religious spirituality in his restoration of Goō Shrine 護王神社 (2002) on Naoshima 直島, Kagawa Prefecture (figure 11). The ambiguities of racial and cultural identity, of political and cultural commitments, and most importantly, of belief (as the suspension of judgment) are chief concerns among the post-economic bubble generations searching for something to invest and believe in.

At the extreme other end of the spectrum, at cynicism, we have the late 1990s works of Murakami Takashi. In the Milk and Cream (ca. 1998) series, for example, Murakami used a meticulous style to depict white bodily fluids projected in jagged arabesques across the matte acrylic surface of the canvas. Several pieces in these series refer to specific works of premodern Japanese art that emphasize the two-dimensionality of the picture surface through the use of dynamic lines. The young Murakami might have been the anti-Kambe, confessing a "hidden ambition of forcing nihonga to its death" 46 and encouraging others to see him not as an active creator, but in his words, as the flawed product of the problematic system of art education and display in postwar Japan. Yet it is significant that Murakami, since his student days in the early 1990s, was deeply concerned with the uneasy relationship between $n i$ honga and contemporary art at large, even declaring in his $1993 \mathrm{PhD}$ dissertation that he sought to "synchroniz[e] Nihonga's rules with the rules of contemporary art." ${ }^{47}$ Since 1993, a number of artists have shown similar ambitions, successfully escaping the financial and ideological control of conservative nihonga groups and reaching a broader audience. The same can be said of artists working in bamboo, lacquer, textiles, ceramics, and calligraphy, and these groups have had the additional advantage of being able to reach back to the progressive 1950 s to 1970 discourse of the nonfunctional objet.

What is most notable about the recent three-dimensional works surveyed in this exhibition is that in contrast to an artist such as Yagi Kazuo, who was catholic in his references to Euro-American, Russian, or Japanese cultural heritage, artists like Someya Satoshi 染谷 聡 (b. 1983) return to the past in order to reevaluate a tradition-based medium and format like lacquer and its relation to Japanese cultural heritage. Mr. Owanjūzaburō (2011) is a small, nonfunctional lacquer objet with a golden miso soup bowl (owan お椀) in place of a face (figure 12). The figure sits atop a tray of rice grains and sports a severed foot; its arms are folded in defiance and its body is covered in Someya's hallmark iconography, a cryptic set of elements that seem to reference tradi- 


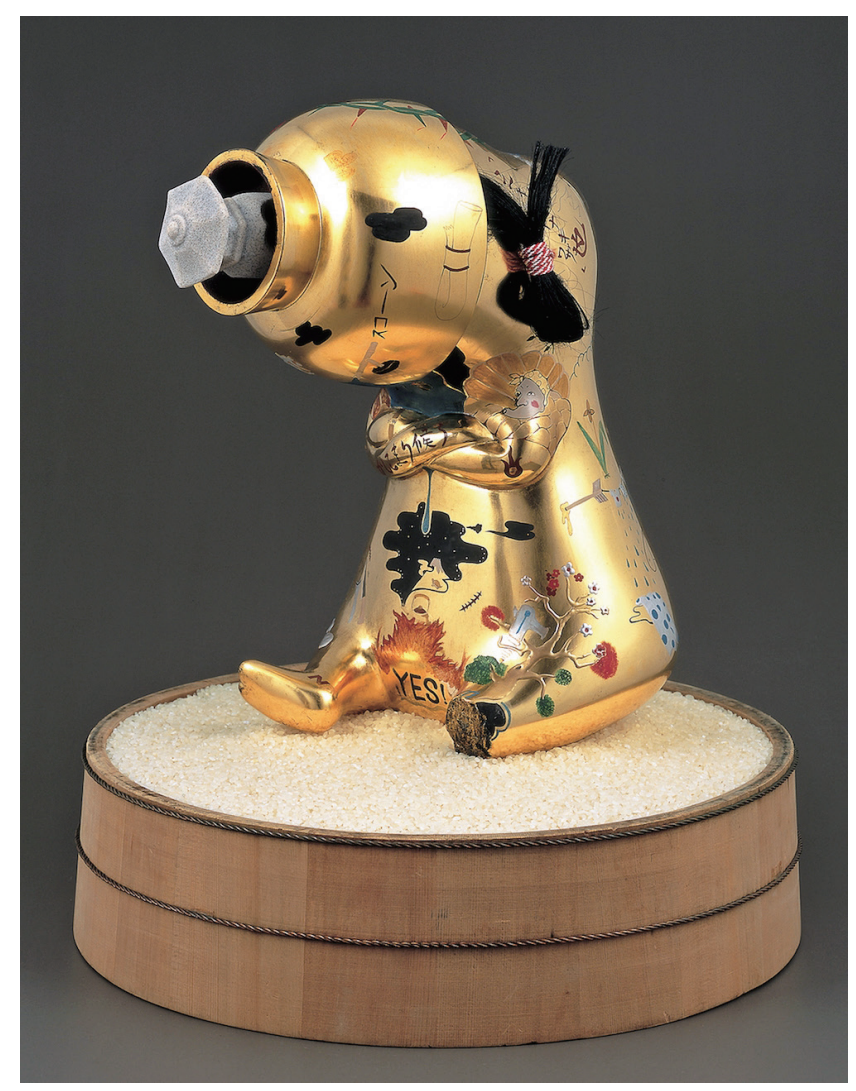

Figure 12. Someya Satoshi. Mr. Owanjūzaburō. 2011. Lacquer, gold, silver, miso soup bowl, and human hair. $30 \times 30 \times 64 \mathrm{~cm}$. Photograph courtesy of Someya Satoshi, with permission to publish.

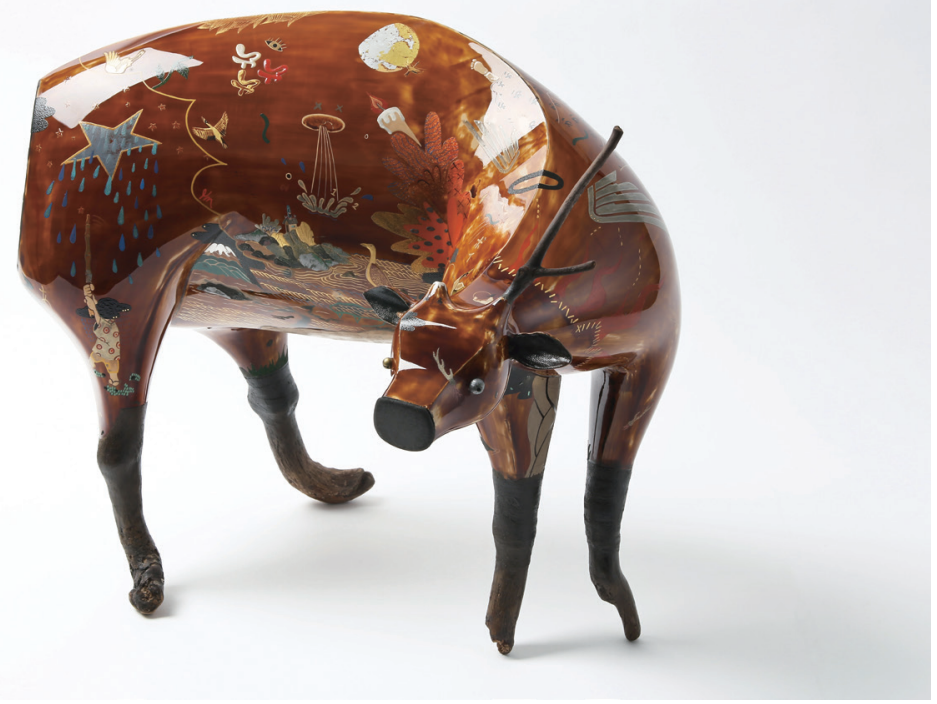

Figure 13. Someya Satoshi. Displayism: Deer 2. 2016. Lacquer, gold, silver, deer bone, and antler. $37 \times 43 \times 37 \mathrm{~cm}$. Photograph courtesy of Someya Satoshi, with permission to publish. 
tion, mythology, and violence. As a maker of the first generation of nonfunctional craft objects, Yagi firmly established the autonomy of his non-vessels; Someya's Mr. Owanjūzaburō, by contrast, embodies ambivalence: it represents the post-1990 trend of reflecting on the fraught boundaries between functionality and display, tradition-based and modernist art. ${ }^{8}$ Like Murakami or Aida, Someya also asks viewers to reflect on the ideological functions of art and of iconography that looks Japanese. The appeal of such artists outside Japan shows that the questions they address have widespread currency. At the same time, these artists leave open the question of whether the global contemporary art market and art audiences can maintain interest in art that lacks any obvious visual reference to the Japanese past.

\section{Conclusion}

In the late nineteenth and early twentieth centuries, Japanese artists and commentators debated whether and how Japanese art should be allowed to "progress" to the level of contemporary Western art; they also speculated about how the emphasis on preserving past techniques could possibly be combined with young artists' ambitions to create something new and unprecedented (shinki 新奇, kakushin 革新). ${ }^{49}$ In the early 1900 and again in the 1950s, some people opined that the past was crippling Japanese art.

At the same time, as Someya alludes to in his Displayism series, the intense changes of the Meiji Restoration of 1868 and beyond made it difficult for twentieth-century Japanese creators to establish a sense of total continuity with Edo-period artists and craftspeople. Before the institution of public exhibitions modeled on the world's fairs and other European exhibitions began in the early 1870 s, there were few spaces in Japan where an artist would have been obliged to produce a painting or vessel and show it to a vast number of unfamiliar viewers. The lacquered deer in Someya's Displayism series allude to the disjuncture and distortion that continue to accompany lacquer arts' fundamental shift from the temple or individual patron's home to the exhibition space: one forlorn-looking deer in Someya's series gleams with lavish maki-e 蒔絵 (lacquer with sprinkled decoration), but its feet are composed of weathered and eroded driftwood. Another deer in the series has no head, but only a delicate antler that morphs directly into a lacquered body covered in minutely detailed but cryptic Japanese-style iconographic elements (figure 13). A third Displayism work consists of a deer skull that underwent kintsugi 金継ぎ, the lacquer and gold repairs reserved for precious objects. Rather than restoring the skeleton, however, Someya's kintsugi interventions seem to highlight its macabre state.

In "The Muddle of Modernity," Chakrabarty writes:

Modernity in the West thus alludes to two separate projects that are symbiotically connected. One refers to processes of building the institutions (from parliamentary and legal institution to roads, capitalist businesses, and factories) that are invoked when we speak of modernization. The other refers to the development of a degree of reflective, judgmental thinking about these processes. The latter is what is often invoked by the term "modernity. ${ }^{50}$

Japanese art entered the age of modernist self-reflection and analysis in the 1890s, when artists outside Europe and America's great metropolises were rarely afforded consideration. Within Japan, there were limits on free expression and the domination of the art market and exhibition spaces by politically and artistically conservative forces whose power continued into the postwar era. ${ }^{51}$ In the wake of this fraught history, some critically and financially successful works of modern Japanese art used large, alluring surfaces, the suspension of time, and, eventually, an immersive environment to minimize self-consciousness and reflection on problems such as whether and how art must address the problem of a modern construct called "tradition."

In their spirituality and transcendentalism, such works trace a partial legacy back to the nihonga of the 1910 s to 1930 s that, particularly in the folding screen format, began to envelop the viewer in a motionless, geographically unbounded and peaceful space (figure 14)..$^{52}$ If these nihonga works can be seen as occupying one end of a spectrum, the other end of the spectrum
48 In art history, these reflections were stimulated by works by Kitazawa (Me no shinden), Satō (Modern Japanese Art), and Mori (Nihon "kogei" no kindai), among others.

49 Foxwell, "The Painting of Sadness?," pp. 34-35.
50 Chakrabarty, "The Muddle of Modernity," p. 669.

51 Kitazawa, "The Genesis of the Kōgei (Craft) Genre."

52 Foxwell, "The Painting of Sadness?" 

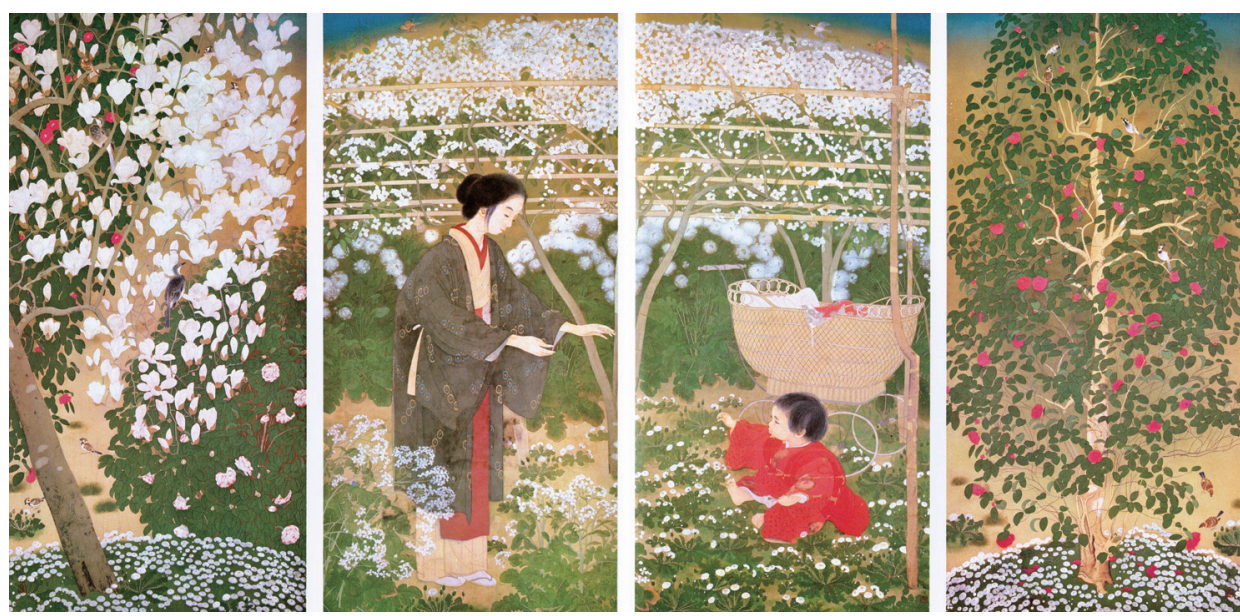

Figure 14. Tsuchida Bakusen. Spring. 1920. Ink and mineral pigments on silk; framed triptych. Kodansha Noma Memorial Museum.

contains art such as Murakami's or Aida's from the mid-1990s to around 2010, which cite tradition only to make viewers aware of the culturally essentialist forces behind it. Somewhere in the middle, Kimura Ryōko and Someya Satoshi transmit time-honored techniques and attitudes from the past, but they also call attention to the modern institutional history that forever changed Edo-period Japanese painting, lacquerware, textile design, and other mediums. If modernism, as Chakrabarty notes, almost always involves some degree of self-conscious "judgmental thinking" about one's own modus operandi, then the artists featured in the Garden of Unearthly Delights and Imayō exhibitions have no trouble meeting those criteria. It remains to be seen, however, whether the global contemporary art world has room for contemporary Japanese artists who are not interested in "tradition."

\section{Reference List}

Adachi Gen 足立元. Zen'ei no idenshi: Anakizumu kara sengo bijutsue 前衛の遺伝子: アナキズムから戦後美術 ح. Brücke, 2012.

Aida, Makoto, Tomoaki Kawai, and Yusuke Tamari. Makoto Aida: Cynic in the Playground. 2003. San Francisco: Viz Pictures. DVD.

Artsy Editors. "The 15 Most Influential Art Cities of 2015.” https://www.artsy.net/article/artsy-editorialcontemporary-art-s-most-influential-cities.

Bann, Stephen. The Clothing of Clio: A Study of the Representation of History in Nineteenth-Century Britain and France. Cambridge University Press, 1986.
Chakrabarty, Dipesh. "AHR Roundtable: The Muddle of Modernity." American Historical Review 116 (2011), pp. 663-75.

Chave, Anna C. "Revaluing Minimalism: Patronage, Aura, and Place." The Art Bulletin 90:3 (2008), pp. 466-86.

Crary, Jonathan. Techniques of the Observer: On Vision and Modernity in the Nineteenth Century. MIT Press, 1990.

Fidler, Luke. "Stumbling Through a Stony Field." NewCity Art, 7 October 2016. https://art.newcity.com/2016/10/o7/ stumbling-through-a-stony-field/.

Foxwell, Chelsea. "Crossings and Dislocations: Toshio Aoki (1854-1912), A Japanese Artist in California." Nineteenth-Century Art Worldwide 11:3 (Fall 2012). https://www.19thc-artworldwide.org/autumn12/ foxwell-toshio-aoki-a-japanese-artist-in-california.

Foxwell, Chelsea. "The Painting of Sadness? The Ends of Nihonga, Then and Now." ARTMargins 4:1 (2015), pp. 27-6o.

Foxwell, Chelsea. "The Total Work of Art: Takashi Murakami and Nihonga." In Takashi Murakami: The Octopus Eats Its Own Leg, ed. Michael Darling, pp. 39-50. New York: Skira Rizzoli Publications, in Association with MCA Chicago and Kaikai Kiki LLC, 2017.

Furuta Ryō 古田亮. Nihonga to wa nan datta no ka: Kindai nihonga shiron 日本画とは何だったのか: 近代日本画史 論. Kadokawa, 2018.

Glaser, David J. “Transcendence in the Vision of Barnett Newman." Journal of Aesthetics and Art Criticism 40:4 (Summer 1982), pp. 415-20.

Gray, Alex. "China Has Overtaken the U.K. as the World's Second-Largest Market for Art." World Economic Forum, 19 March 2018. https://www.weforum.org/agenda/2018/ 
03/china-is-second-largest-art-market-in-world/.

Guth, Christine. Art, Tea, and Industry: Masuda Takashi and the Mitsui Circle. Princeton University Press, 1993.

Hearn, Maxwell K. Ink Art: Past as Present in Contemporary China. New York: Metropolitan Museum of Art, 2013.

Holland, James-Henry II. "A Public Tea Gathering: Theater and Ritual in the Japanese Tea Ceremony." Journal of Ritual Studies 14:1 (2000), pp. 32-44.

Horowitz, Gregg M. Sustaining Loss: Art and Mournful Life. Stanford University Press, 2002.

Kee, Joan. "Points, Lines, Encounters: The World According to Lee Ufan." Oxford Art Journal 31:3 (2008), pp. 403-24.

Kelmachter, Hélène. "Interview with Takashi Murakami, pp. 72-105. In Takashi Murakami Kaikai kiki, Fondation Cartier pour l'art contemporain, Paris, 2002.

Kitazawa Noriaki. "The Genesis of the Kögei (Craft) Genre and the Avant-Garde: Surrounding the Creation of the Tokyo Municipal Museum of Art." 2 vols. Trans. Chelsea Foxwell. In East Asian Design History Reader 2, ed. Yūko Kikuchi. Forthcoming 2019.

Kitazawa Noriaki 北澤憲昭. Me no shinden: Bijutsu juyōshi nōto 眼の神殿:「美術」受容史ノート. Bijutsu Shuppansha, 1989.

Kitazawa Noriaki. "Rettō" no kaiga: "Nihonga" no reito sutairu「列島」の絵画:「日本画」のレイト・スタイル. Brücke, 2015.

Latour, Bruno. We Have Never Been Modern. Harvard University Press, 1991.

Martin, Holly E. “The Asian Factor in John Cage's Aesthetics: An Introduction with a Previously Unpublished Interview from 1976." Black Mountain College Studies Journal 9 (2016). http://www.

blackmountainstudiesjournal.org/volume-iv-9-16/ holly-martin-the-asian-factor-in-john-cages-aesthetics/.

Mori Hitoshi 森仁史. Nihon koggei no kindai: Bijutsu to dezain no botai to shite 日本「工芸」の近代: 美術とデザイ ンの母体として. Yoshikawa Kōbunkan, 2009.

Moxey, Keith. Visual Time: The Image in History. Duke University Press, 2013.

Murakami Takashi 村上隆. “Bijutsu ni okeru 'Imi no muimi no imi’ o megutte: Aura no netsuzō o kōsatsu suru” 美術 における「意味の無意味の意味」をめぐって: アウラの捏 造を考察する. PhD dissertation, Tokyo University of the Arts, 1993.

Murakami Takashi, ed. Little Boy: The Arts of Japan's Exploding Subculture. New York: Japan Society and Yale University Press, 2005.

Okakura Kakuzō. The Book of Tea. New York: Duffield \& Company, 1906.
Pollock, Sheldon. The Ends of Man at the End of Premodernity. Amsterdam: Royal Netherlands Academy of Arts and Sciences (KNAW), 2005.

Reynolds, Jonathan. Allegories of Time and Space: Japanese Identity in Photography and Architecture. University of Hawai'i Press, 2015.

Roquet, Paul. Ambient Media: Japanese Atmospheres of Self. University of Minnesota Press, 2016.

Rosenfield, John M. "Nihonga and Its Resistance to 'the Scorching Drought of Modern Vulgarity.” In Births and Rebirths in Japanese Art: Essays Celebrating the Inauguration of the Sainsbury Institute for the Study of Japanese Arts and Cultures, ed. Nicole Coolidge Rousmaniere, pp. 162-97. Leiden: Hotei Publishing, 2001.

Russel, Karen Kramer. Shapeshifting: Transforming in Native American Art. Peabody Essex Museum in association with Yale University Press, 2012.

Satō, Dōshin. Modern Japanese Art and the Meiji State: The Politics of Beauty. Trans. Hiroshi Nara. Los Angeles: Getty Research Institute, 2011.

Sutton, Gloria. The Experience Machine: Stan VanDerBeek's Movie-Drome and Expanded Cinema. MIT Press, 2015.

Sutton, Gloria. "Stan VanDerBeek's Movie-Drome: Networking the Subject." In Future Cinema: The Cinematic Imaginary After Film, ed. Jeffrey Shaw and Peter Weibel, pp. 136-43. MIT Press, 2003.

Wakasa, Mako. "Interview with Takashi Murakami." New York, 200o. Journal of Contemporary Art. http://www. jca-online.com/murakami.html.

Weisenfeld, Gennifer. "Publicity and Propaganda in 1930 s Japan: Modernism as Method." Design Issues 25:4 (2009), pp. 13-28.

Weisenfeld, Gennifer. "Reinscribing Tradition in a Transnational Art World (2007)." In Contemporary Art in Asia: A Critical Reader, ed. Melissa Chiu and Benjamin Genocchio, pp. 371-90. MIT Press, 2011.

Yiengpruksawan, Mimi Hall. Review of Nihonga, Transcending the Past: Japanese-Style Painting, 18681968, by Ellen P. Conant, Stephen Owyoung, and J. Thomas Rimer. The Journal of Japanese Studies 25:1 (1999), pp. 161-66. 